\title{
Research on the Engineer Training Mode of German University of Applied Sciences
}

\author{
Kai Shi* \\ School of Optoelectronic Engineering \\ Xi'an Technological University \\ Xi'an, China \\ shikai@xatu.edu.cn
}

\author{
Weiguang Zhang \\ School of Optoelectronic Engineering \\ Xi'an Technological University \\ Xi'an, China
}

\begin{abstract}
The quality of German products is worldrenowned, mainly due to its unique engineer training model. This paper introduces the development of German engineer training mode firstly. It discusses the unique engineer training mode of the German University of Applied Sciences from three aspects: training concept, training goal and training mode. Furthermore, it provides ideas for the development of engineering education in local undergraduate colleges in view of the problems faced in the development and reform of higher education in China.
\end{abstract}

Keywords-Germany; university of applied sciences; engineer; training mode; local universities

\section{INTRODUCTION}

As the EU's first economy, Germany has a strong economic strength and a high degree of social welfare. It also implements a free system for education, including various types of higher education. Students usually receive education at the university for a fee of between 100 and 300 euros per semester. The school usually provides students with services such as student dormitories and student canteens below the market price, and provides subsidies or loans to students in need so that they can complete higher education independently and loosely. At present, higher education institutions are divided into four categories in Germany according to the tasks and orientation of higher education: University, University of Applied Sciences, College of Art and Music, Career College.

German manufacturing has always been synonymous with high quality in the international market, especially in China. From German beer, Zwilling wok, Zeiss camera to Siemens, Mercedes-Benz and BMW, etc., German manufacturing has a high degree of recognition in China. With the rapid development of China's economy, the trade volume between China and Germany is also increasing year by year. According to the German Federal Statistical Office, the total trade volume between China and Germany reached 186.6 billion euros in 2017. And China became the largest trading partner of Germany for the second consecutive year [1]. According to the Eurostat, the trade volume between China and the EU in 2017 was 573 billion euros, and Sino-German trade accounted for $32.6 \%$ of the trade between China and the EU [2]. The reason why German manufacturing is so attractive is that it has a

Teaching Reform Research Project of Xi'an Technology University of Optoelectronic Engineering College (17GDJG02). Teaching Reform Research Project of Xi'an University of Technology (18JGY01). Xi'an Technology University of 2018 Graduate Education Reform Key Project (XAGDYJ180101) unique basic education system and vocational training system. Mainly due to its unique engineer training model.

\section{THE DEVELOPMENT OF GERMAN ENGINEERS TRAINING MODE}

High-quality products come from excellent engineers, and the training of German engineers has its own unique features. German higher education has a long history and high popularity. There are 376 colleges and universities in Germany, distributed in 16 federal states. The ancient Heidelberg University was founded in 1386 and is the oldest university in Germany. The Humboldt University, founded by the Humboldt brothers in 19th century, produced 29 Nobel Prize winners.

After the Second World War, the German economy quickly rose from the ruins and once again became the world's industrial power. Tens of thousands of high-quality engineers and technicians are major contributors [3]. And this is the great achievement of the development of German engineering education.

On the one hand, the Federal Republic of Germany was influenced by the American engineering education training mode and the third industrial revolution. Its engineering education began to be integrated and internationalized in terms of training content and training methods. On the other hand, Democratic Germany was mainly influenced by the Soviet model. Due to the relatively high level of state intervention, the scale of engineering education in Democratic Germany has developed by leaps and bounds. In short, both East and West Germany attach great importance to the development of engineering education, cultivated a large number of engineers, and formed a relatively complete engineer training model.

At present, the German higher education industry is reforming and innovating on the basis of tradition. In 2005, the German elite university program initiated and funded by the German government began to start. This activity, which is dominated by the German elites and elite graduate schools, has given great support to German universities in developing cutting-edge research programs. Today, the training of engineers in Germany is mainly undertaken by the University of Technology and the University of Applied Sciences. The University of Science and Technology is mainly responsible for cultivating research-oriented engineers, focusing on the 
establishment of students' theoretical knowledge and advocating the spirit of innovation. So that students have a perfect scientific knowledge system and engineering research ability when they graduate. While Applied Technology University is mainly responsible for cultivating applied engineers. Undergraduate training, application development and enterprise-oriented research, curriculum and professional settings focus on matching with the application direction of enterprises to cultivate application-oriented professionals with independent professionalism [4]. This clear classification and accurate positioning of the training mode has become one of the typical representatives of engineers in the world. In this model, Germany has cultivated a large number of engineers. It provides the necessary talent conditions for Germany's manufacturing reputation and makes a great contribution to enriching the world's engineer training model.

\section{TRAINING MODE OF ENGINEERS FROM THE UNIVERSITY OF APPLIED SCIENCES}

The German University of Applied Sciences referred to as FH was founded in the late 1960s and early 1970s. After half a century of development, the University of Applied Sciences has developed into an engineering application university with the goal of cultivating applied talents. An application-oriented talent training system focusing on the improvement of engineering ability with the aim of cultivating application engineers is constructed. In the beginning, the University of Applied Sciences mainly set up a small number of applied majors for specific positions. And the names are called higher professional colleges. With the resolutions of the 1998 Joint Meeting of German Ministers of Culture (KMK) and the Joint Conference of University Presidents (HRK), the higher professional colleges have since unified the use of the English title "University of Applied Sciences" [5]. These universities aim to train undergraduates and actively develop postgraduate education in application development and enterprise orientation. They focus on the cultivation of students' engineering practice ability and are the main talent base for engineers in various German companies.

In Germany's "Higher Education Reform and Development Plan for the 21st Century", Germany will form a new pattern of higher education with FH as the mainstay. Moreover, as a "German experience", it has been promoted in other countries around the world [6]. Although the German University of Applied Sciences has only a half-century history of running a school, its school philosophy and training model that meets social needs has led to its rapid expansion. It has become the second largest type of higher education in Germany. According to the German Federal Statistical Office, the number of students enrolled in German universities in the 2017/2018 academic year is about 2.84 million, of which 1.75 million are comprehensive universities, accounting for $61.6 \%$ of the total number. The number of students enrolled in the University of Applied Sciences is about 0.97 million, accounting for only $34.1 \%$ of the total number of all students, but it has trained 2/3 of Germany's engineers [7], which is a veritable engineer cradle.

\section{A. Training concept}

The German training model is called "European Continent Model" by historians, adhering to the rigorous and elite engineer training concept. The rigorous working attitude of the Germans always runs through his national will. Both daily necessities and industrial products are strictly designed and manufactured according to the craftsmanship spirit unique to their engineers. In the long process of development of this national will, the rigorous and elite engineer training concept has been continuously improved and strengthened. Under the guidance of this concept, a large number of high-level engineers have emerged in Germany.

The German nation in history is a nation that is good at speculation. The philosophers such as Kant, Hegel, and Feuerbach have created glory in the history of philosophy. Then, the famous German educator William Humboldt created Humboldt University [8]. As Humboldt believes: the university is at the top of the academic level and should have a rigorous training philosophy. Because of this, the development of German modern higher education has inherited the traditional German national will and Humboldt spirit, and gradually formed a rigorous and elite engineer training concept that emphasizes engineering application. In addition, the formation of German engineers' training concept is to a certain extent. It is also influenced by the culture of technicians and mercantilism. For example, from the discussion of mercantilism by Adam Smith and others [9], these training concepts are the basis for forming a unique training model for German engineers. The core of the engineer training model is also the source of continuous improvement in the German engineering training system.

\section{B. Training objectives}

After more than half a century of development, the German University of Applied Sciences has set its training objectives based on the actual employment needs of students. Its training objectives are based on changes in social and economic development and changes in corporate needs, and advocated that "Applied Technology University hopes to graduate from its own trained closer to customers". The Agreement on the Unified College of the Federal Republics states that the University of Applied Sciences should educate students on the basis of traditional theories. Finally, students can engage in independent professional activities through the nationally prescribed graduation test. On this basis, the University of Applied Sciences aims at the needs of economic and social development. Emphasis is placed on the ability of students to comprehensively apply different knowledge and skills to solve engineering problems facing enterprises, that is, mainly for advanced application engineers. This requires students to have sound scientific literacy and master the system's expertise. However, it is mainly not engaged in scientific research work. More importantly, it accepts systematic engineering training and has basic skills for engineers facing enterprises.

Different from the comprehensive university, the University of Applied Sciences cultivates high-level applied talents with a solid professional foundation and strong engineering application ability. It is called advanced 
application talents to solve different engineering problems [10]. In summary, the German University of Applied Sciences aims to cultivate application-oriented professionals with independent professionalism, that is, to cultivate application engineers.

\section{Training method}

The engineering education of the University of Applied Sciences can usually integrate theoretical teaching with practical teaching. The proportion of academic and experimental training is far greater than that of ordinary comprehensive universities. In the construction of its disciplines, it attaches importance to the construction of engineering laboratories and is good at introducing the management mode of enterprises. It is good at guiding students to exercise their engineering practice ability to achieve the purpose of teaching for the needs of enterprises. The University of Applied Sciences also widely adopts the "dual system" approach to work closely with local businesses to jointly train students, and universities and enterprises are jointly responsible for their respective training tasks. The corresponding credits are obtained through the teaching activities organized by the school. Students can apply for a graduation reply and pass the degree certificate issued by the school. At the same time, students can complete the internship assignments in accordance with the relevant regulations, and can participate in the professional certification examinations of organizations or industry associations, and obtain professional certificates. The university is responsible for the training of students' professional theoretical knowledge. The company is responsible for the practical skills training of the students. Under the joint efforts of the university and enterprise, the first-class quality engineers are trained.

At the same time, the "double-type" teachers also provide guarantees for the school to train qualified engineers. On the one hand, the University of Applied Sciences is different from the multi-level faculty of the comprehensive university. The teacher's title level is the only professor, and the other is classified as a teaching assistant. In addition to the usual conditions, professors of these universities must have at least 5 years of practical work experience in the application or development of their fields of expertise, requiring at least three years of work outside the university [11]. Therefore, the professors of the University of Applied Sciences have worked in the enterprise and have been responsible for specific engineering and technical projects, and can pass on detailed engineering and technical experience to students. At the same time, most of them also maintain cooperative relations with enterprises. These social resources will create a good practice and employment opportunities for students, and correspondingly realize the simultaneous development of teaching content and engineering practice [4]. On the other hand, the University of Applied Sciences will hire a large number of off-campus special teachers from companies and research institutions. This is a supplement to full-time professors on campus, achieving a balance of knowledge and skills. Distinguished teachers teach one or more courses to the university all year round. The practical work experience of the company for many years is conducive to the cultivation of students' engineering application ability, and the changing professional characteristics of production practice can be added to the teaching content to show students. Moreover, they will become a bridge between enterprises and universities, helping universities to directly acquire the real needs of enterprises, and also reserve strength for the future development of enterprises.

\section{ENLIGHTENMENT TO CHINA'S HIGHER EDUCATION}

Compared with the training mode of engineers in the German University of Applied Sciences, there are many problems in engineering education in China's higher education. Mainly manifested in: the averaging of higher education, the lack of training for senior application engineers targeting the market, local undergraduate university is not reasonably complete the transformation and development to meet the needs of applied talents. There is insufficient cooperation between universities and enterprises, and it is impossible to cultivate students' engineering skills according to the needs of enterprises. At the same time, enterprises are not actively involved in the process of talent cultivation. Universities and enterprises have not established a joint engineer training model for engineering needs. The management department did not put forward the development ideas of engineering education in colleges and universities and formulated relevant reform measures. There is no active guidance for different types of colleges and universities to implement the development path that suits their respective characteristics, especially local colleges with unique academic characteristics.

At present, China is accelerating the development process of new industrialization, deepening reforms, and building a key stage of an innovative country. It is urgent to cultivate a large number of application-oriented talents who are innovative in their ability to meet market demands. Therefore, the Ministry of Education has implemented the "Excellent Engineer Education and Training Program" and the "Engineering Education Professional Certification”. In the implementation of these reforms, we can learn from the characteristics of local undergraduate colleges. In addition, we can focus on exploring the successful experience of German engineers and actively support local colleges and universities to apply for international cooperation education. By combining the actual situation of engineering education in China, we explore innovative training models of applied engineers and cultivate high-quality engineering and technical personnel.

\section{CONCLUSION}

This paper, through the research on the training mode of engineers in the German University of Applied Sciences, is based on the cultivation of applied talents. According to the actual needs of enterprises and social organizations, it is open to enterprise-oriented majors, especially in the professional fields such as engineering technology and enterprise economy, and rely on practical teaching mode. Strengthen the cultivation of high-level applied and skilled talents with strong practical skills. Finally, most ordinary universities, have not played their respective advantageous resources and seek a closer cooperation model with the enterprise market. It should form a professional setting, teaching mode and teacher strength based 
on the premise of school-enterprise cooperation based on the characteristics of the university. It enables domestic ordinary colleges and universities to truly cultivate applied engineering talents and has their own unique school-running model.

\section{REFERENCES}

[1] http://munich.mofcom.gov.cn/article/jmxw/201802/20180202714177. shtml

[2] http://eu.mofcom.gov.cn/article/jmxw/201803/20180302724688.shtml

[3] G.J Yu, H. Jiang, W. Xu, "German experience cultivated by excellent engineers,” Higher Education Exploration, 2015, vol. 2, pp. 66-69. (In Chinese)

[4] K. Shi, J. Liu, "Research on the Classification and School Running Model of German Universities," Heilongjiang Researches on Higher Education, 2015, vol. 7, pp. 61-64. (In Chinese)
[5] Wissenschaftsrat. Empfehlungen Zur Rolle der Fachhochschulen im Hochschulsystem, Koeln, WR, 2010.

[6] H. Ru, J.W. Yu, "A Summary of German FH and Its Technology Development Strategy,” Journal of Suzhou College of Education, 2007, vol. 2, pp. 72-74. (In Chinese)

[7] F. Jiang, "University of Applied Sciences: German engineer cradle," CHINA EDUCATION DAILY, 2014-05-07(002). (In Chinese)

[8] H.J. Chen, "For academic or professional?-Learning traditions and changes in German universities," Peking University Education Review, 2005, vol. 2, pp. 75-78. (In Chinese)

[9] A. Smith, "The Wealth of Nations," The Next Volume, The Commercial Press, 1974.

[10] Y.N. Huang. "Analysis of the characteristics of FH practice teaching mode in Germany,” Vocational and Technical Education, 2004, vol. 25, pp 67-69. (In Chinese)

[11] Landestag Baden-Württemburg. Gesetzblatt für Baden-Württemburg [EB/OL].2012-06-02 